\title{
UPAYA MENINGKATKAN HASIL BELAJAR SISWA PADA MATA PELAJARAN IPS MATERI AKTIVITAS EKONOMI DENGAN MENGGUNAKAN MODEL PEMBELAJARAN KOOPERATIF TIPE MAKE A MATCH DI KELAS IV MIN MEDAN TEMBUNG TAHUN AJARAN 2016/2017
}

\author{
Syarifah Aini, Athiyyah Zahrah Al Fananie
}

Surel: Syarifahaini10@gmail.com,Athiyyahzahrah44@gmail.com

\begin{abstract}
Abstrak
Penelitian ini bertujuan untuk mengetahui (1) hasil belajar sebelum menggunakan Model Pembelajaran Kooperatif Tipe Make A Match pada mata pelajaran IPS Materi Aktivitas Ekonomi di kelas IV MIN Medan Tembung, (2) hasil belajar setelah menggunakan Model Pembelajaran Kooperatif Tipe Make A Match pada mata pelajaran IPS materi Aktivitas Ekonomi di kelas IV MIN Medan Tembung, dan (3) Penerapan menggunakan Model Pembelajaran Kooperatif Tipe Make A Match pada mata pelajaran IPS yang dapat meningkatkan hasil belajar siswa kelas IV MIN Medan Tembung. Penelitian ini berupa PTK (Penelitian Tindakan Kelas), dengan subjek penelitian berjumlah 35 siswa. Kesimpulan dari hasil penelitian adalah: (1) hasil belajar siswa sebelum tindakan mendapat nilai rata-rata 71,42, siswa yang tuntas sebanyak 34,29\% (12 siswa). (2) hasil belajar siswa setelah diterapkan Model Pembelajaran Kooperatif Tipe Make A Match pada siklus I nilai rata-rata menjadi 77,72 siswa yang tuntas sebanyak 62,86\% (22 siswa). (3) hasil belajar siklus II nilai rata-rata meningkat menjadi 82 siswa yang tuntas sebanyak $80 \%$ (28 siswa).
\end{abstract}

Kata Kunci : Model Pembelajaran, Kooperatif Tipe Make A Match, Hasil Belajar.

\section{PENDAHULUAN}

Dalam istilah asing, "Pendidikan" itu disebut "Paedagogiek". Mulanya "Paedagogiek" dimaksudkan budak yang pandai dan dewasa yang diserahkan (ditugaskan) untuk mengantar anak tuannya ke sekolah sambil membawa alat-alat sekolahnya. Pengertian tugas ini kemudian diperluaskan menjadi kewajiban membimbing moral dan tingkah laku anak, sehingga sekarang istilah "Paedagogiek" berarti ilmu tentang perbuatan mendidik, "Paedagoog" berarti ahli didik atau pendidik.

Selanjutnya, pendidikan adalah pertolongan yang diberikan oleh orang dewasa yang bertanggung jawab terhadap perkembangan anak untuk menuju ketingkat dewasa. Oleh karena itu, dari kesimpulan diatas dapat disimpulkan bahwa pendidikan adalah bimbingan atau pengajaran secara sadar oleh si pendidik terhadap perkembangan jasmaniah dan rohaniah anak didik demi terwujudnya

Program Pascasarjana Pendidikan Dasar Universitas Negeri Medan

Program Pascasarjana Pendidikan Dasar Universitas Negeri Medan 
tujuan pendidikan. Dalam mencapai tujuan pendidikan banyak faktor yang mempengaruhi untuk terwujudnya tujuan pendidikan tersebut.

Tujuan pendidikan nasional merupakan tujuan pendidikan yang paling tinggi dalam hirarki tujuan-tujuan pendidikan yang ada, yang bersifat ideal dan umum. Menurut Undang-undang No.2 Tahun 1989 tentang Sistem Pendidikan Nasional, tujuan pendidikan Nasional adalah untuk menciptaan manusia Indonesia yang beriman, bertakwa terhadap Tuhan Yang Maha Esa, berbudi pekerti luhur, memiliki pengetahuan dan keterampilan, kesehatan jasmani dan rohani, kepribadian yang mantap, mandiri dan memiliki rasa tanggung jawab kemasyarakatan dan kebangsaan. Jelas dalam penjelasan diatas, bahwa tujuan pendidikan adalah hal yang sangat penting serta dalam prosesnya membutuhkan waktu yang sangat lama. Berdasarkan keterangan tujuan diatas siswa dibimbing dan diarahkan perkembangannya, sehingga menghasilkan pendidikan yang berkualitas.

Pendidikan IPS merupakan salah satu mata pelajaran yang dapat memberikan wawasan pengetahuan yang luas mengenai masyarakat lokal maupun global sehingga mampu hidup bersama-sama dengan masyarakat lainnya. Selanjutnya,tujuan pendidikan IPS adalah membekali anak didik dengan pengetahuan sosial yang berguna dalam kehidupan bermasyarakat.

Dalam pasal 37 UU Sisdiknas dikemukakan bahwa mata pelajaran IPS merupakan muatan wajib yang harus ada dalam kurikulum pendidikan dasar dan menengah. Lebih lanjut dikemukakan pada bagian penjelasan UU Sisdiknas pasal 37 bahwa bahan kajian ilmu pengetahuan sosial, antara lain, ilmu bumi, sejarah, ekonomi, kesehatan, dan sebagainya dimaksudkan untuk mengembangkan pengetahuan pemahaman, dan kemampuan analisis peserta didik terhadap kondisi sosial masyarakat.

Pada pembelajaran IPS terdapat banyak jenis model pembelajaran yang dapat digunakan sebagai metode pembelajaran IPS. Model pembelajaran alternatif untuk bidang ilmu-ilmu sosial seperti: Model inkuiri, problem solving, berfikir kritis, pengambilan keputusan dan lain sebagainya. Model pembelajaran kooperatif tipe Make A Match (Mencari Pasangan) ini merupakan model pembelajaran yang mana siswa diajak untuk mencari pasangan sambil belajar mengenai suatu konsep atau topik dalam suasana yang menyenangkan. Selanjutnya, pada model pembelajaran ini menitikberatkan gotong royong atau kerjasama kelompok.

\section{METODE PENELITIAN}

Jenis penelitian ini adalah penelitian Tindakan kelas (PTK). Penelitian memutuskan menggunakan metode ini karena PTK dilaksanakan di dalam kelas ketika proses pembelajaran sedang berlangsung.

Adapun pengertian penelitian tindakan kelas menurut Kunandar adalah: 
Penelitian adalah aktivitas mencermati suatu objek tertentu melalui metodologi ilmiah dengan mengumpulkan data-data dan dianalisis untuk menyelesaikan suatu masalah.

Tindakan adalah suatu aktivitas yang sengaja dilakukan dengan tujuan tertentu yang berbentuk siklus kegiatan dengan tujuan untuk memperbaiki atau meningkatkan mutu atau kualitas proses belajar mengajar.

Kelas adalah sekelompok siswa yang dalam waktu yang sama menerima pelajaran yang sama dari seorang guru.

Sedangkan Menurut Suharsimi Arikunto, pengertian penelitian Tindakan Kelas adalah:

Penelitian menunjukkan pada suatu kegiatan mencermati suatu objek dengan menggunakan cara dan aturan metodologi tertentu untuk memperoeh data atau informasi yang bermanfaat dalam meningatkan mutu suatu hal yang menarik minat dan penting bagi peneliti.

Tindakan menunjukkan pada suatu gerakan kegiatan yang sengaja dilakukan dengan tujuan tertentu. Dalam penelitian berbentuk rangkaian siklus kegiatan untuk siswa.

Kelas dalam hal ini tidak terikat pada pengertian ruang kelas, tetapi dalam pengertian yang lebih spesifik. Seperti yang sudah lama dikenal delam bidang pendidikan dan pengajaran, yang dimaksud dengan istilah kelas adalah sekelompok siswa yang dalam waktu yang sama meneriuma pelajaran yang sama dari guru yang sama pula.

Dari pengertian di atas dapat disimpulkan bahwa Penelitian Tindakan Kelas merupakan suatu pencermatan terhadap kegiatan belajar berupa sebuah tindakan yang sengaja dimunculkan dan terjadi dalam sebuah kelas secara bersama. Tindakan tersebut diberikan oleh guru atau dengan arahan dari guru yang dilakukan oleh siswa.

\section{HASIL PENELITIAN DAN PEMBAHASAN}

Penelitian ini dilakukan dengan upaya yang optimal untuk meningkatkan kemampuan dan hasil belajar siswa pada mata pelajaran Ilmu Pengetahuan Sosial (IPS) materi Kegiatan Ekonomi (Pasar). Langkah pertama yang dilakukan peneliti adalah mengidentifikasi masalah yang akan diteliti berdasarkan hasil wawancara peneliti dengan guru kelas dan hasil pengamatan terhadap siswa dalam mengikuti mata pelajaran Ilmu Pengetahuan Sosial.

Sebelum melakukan tindakan, siswa diberi test awal atau pre test kepada siswa sebanyak 10 soal untuk mengetahui kemampuan siswa sebelum melaksanakan pembelajaran dengan menggunakan model Make A Match. Pemberian soal ini bertujuan untuk mengetahui hasil belajar siswa terhadap mata pelajaran Ilmu Pengetahuan Sosial materi Kegiatan Ekonomi (Pasar). Selain itu juga digunakan untuk mengetahui gambaran-gambaran kesulitan yang dialami siswa dalam menyelesaikan soal-soal tentang materi Kegiatan Ekonomi (Pasar). 
Dari hasil penelitian, sebelum dilaksanakannya tindakan nilai rata-rata kelas pada pra tindakan adalah 71,42 dengan jumlah siswa yang memperoleh nilai 80 keatas sebanyak 12 siswa atau sebesar 33,29 \%. Hal ini dipengaruhi oleh belum adanya penerapan model pembelajaran make a match oleh peneliti. Karena ketuntasan belajar secara klasikal belum tercapai maka dibuat alternative perbaikan skenario pembelajaran.

Kemudian peneliti memberikan tindakan kepada siswa pada siklus I yaitu melalui model pembelajaran make a match. Berdasarkan hasil penelitian, Setelah pemberian tindakan melalui penerapan model pembelajaran make a match yang dilakukan peneliti pada siklus I diperoleh nilai rata-rata siswa 77,72 dengan jumlah siswa yang memperoleh nilai 80 keatas sebanyak 22 siswa atau sebesar $62,86 \%$.

Berdasarkan analisis data siklus I diperoleh kesimpulan sementara bahwa penerapan model pembelajaran make a match yang dilakukan peneliti belum dapat meningkatkan hasil belajar siswa pada materi aktivitas ekonomi. Sehingga perlu perbaikan dan pengembangan dengan menggunakan model pembelajaran make a match.

Pada siklus II siswa memperoleh nilai rata-rata 82 dengan jumlah siswa yang memperoleh nilai 80 keatas sebanyak 28 siswa atau sebesar $80 \%$. Lebih jelasnya peningkatan hasil belajar dapat dilihat rata-rata nilai saat test awal, hasil belajar siklus I dan pada siklus II, seperti tabel dibawah ini:

Tabel 1. Hasil Belajar Siswa Pada Pre Test, Siklus I, dan Siklus II

\begin{tabular}{|l|l|l|}
\hline No & Deskripsi Nilai & Nilai Rata-rata \\
\hline 1 & Test awal & 71,42 \\
\hline 2 & Siklus I & 77,72 \\
\hline 3 & Siklus II & 82 \\
\hline
\end{tabular}

Pada tindakan siklus II merupakan perbaikan pembelajaran yang dilaksanakan pada siklus I. Dari test hasil belajar diperoleh nilai rata-rata kelas meningkat, hal ini berarti pembelajaran dengan menggunakan model pembelajaran make a match yang dilaksanakan peneliti dapat meningkatkan hasil belajar Ilmu Pengetahuan Sosial materi aktivitas ekonomi pada kelas IV MIN MEDAN TEMBUNG. Hal tersebut dapat dilihat pada perubahan hasil belajar siswa dimulai pra tindakan, siklus I hingga siklus II pada grafik berikut:

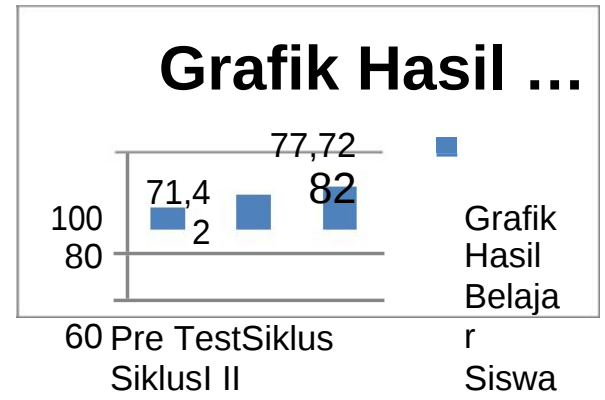

Gambar 1. Grafik Pencapaian Hasil Belajar Siswa 
ISBN: 978-602-50622-0-9 
Walaupun penelitian ini telah berhasil mencapai tujuan yang diharapkan, akan tetapi peneliti mengakui bahwa masih ada kelemahan dalam penelitian yang mempengaruhi keberhasilan dan tuntutan model pembelajaran make a match. Hal ini disebabkan karena keterbatasan yang ada pada peneliti serta adanya kemungkinan siswa kurang sungguh-sungguh dalam menyelesaikan soal test yang diberikan.

Berdasarkan hasil peneliti dan hasil analisis data diperoleh kesimpulan bahwa pembelajaran dengan menggunakan model pembelajaran make a match dapat meningkatkan hasil belajar siswa dalam menyelesaikan soal-soal yang diberikan. Dengan demikian pembelajaran dengan model pembelajaran make a match mempunyai peranan penting sebagai salah satu upaya meningatkan hasil belajar siswa.

Berdasarkan gambar 4.1 bahwa terdapat peningkatan hasil belajar siswa mulai dari pre test, hingga hasil belajar siswa pada siklus I dan siklus II. Berdasarkan analisis data dan pembahasan dapat disimpulkan bahwa penerapan model pembelajaran make a match dapat meningkatkan hasil belajar siswa pada mata pelajaran Ilmu Pengetahuan Sosial pada materi aktivitas ekonomi di kelas IV MIN MEDAN TEMBUNG Tahun Ajaran 2016/2017.

\section{SIMPULAN}

Berdasarkan analisis data pada penelitian ini, maka penulis mengambil beberapa kesimpulan sebagai berikut:

Hasil belajar siswa kelas IV MIN MEDAN TEMBUNG T.A. 2016/2017 pada mata pelajaran Ilmu Pengetahuan Sosial materi aktivitas ekonomi sebelum diterapkannya model pembelajaran make a match masih sangat rendah. Hal ini dapat dilihat dari rendahnya presentase ketuntasan belajar siswa secara klasikal yang hanya 12 dari 35 orang siswa $(34,29 \%)$ yang dinyatakan tuntas dengan nilai rata-rata 71,42.

Hasil belajar siswa meningkat pada setiap siklus. Hal ini terlihat dari hasil penelitian ini berupa peningkatan hasil belajar siswa dalam mata pelajaran Ilmu Pengetahuan Sosial materi aktivitas ekonomi setelah diterapkannya model pembelajaran make a match pada saat siklus I nilai rata-rata kelas 77,72 dengan tingkat ketuntasan 22 orang siswa (62,86\%) sedangkan pada siklus II nilai rata-rata kelas meningkat mencapai 82 dengan tingkat ketuntasan 28 orang siswa $(80 \%)$.

Selama proses pembelajaran dengan menggunakan model pembelajaran make a match respon dan hasil belajar siswa terus mengalami peningkatan. Siswa menjadi lebih aktif dan rasa ingin tahu siswa menjadi besar. Sehingga suasana dalam proses pembelajaran jadi lebih aktif. Dan dengan menggunakan model make a match ini hasil belajar siswa menjadi meningkat dan respon guru terhadap penggunaan model pembelajaran make a match pada pembelajaran Ilmu Pengetahuan Sosial sangat baik, karena 
dengan menggunakan model pembelajaran make a match hasil belajar siswa dapat meningkat dan siswa lebih mudah memahami pelajaran.

\section{DAFTAR RUJUKAN}

A.Bakar, Rosdiana. 2012. Pendidikan Suatu Pengantar. Bandung: Cipta Pustaka Media Printis.

Ananda, Rusdi, dkk. 2015. Penelitian Tindakan Kelas. Bandung: Cipta pustaka Media.

Arikunto, Suharsimi. 2012. Penelitian Tindakan Kelas. Jakarta: PT Bumi Aksara.

Aqib, Zainal, dkk. 2009. Penelitian Tindakan kelas Untuk Guru SD, SLB, dan TK. Bandung: Yrama Widya.

Bahri, Djamarah, Syaiful. 2011. Psikologi Belajar. Jakarta: Rineka Cipta.

Dalyono. 2012. Psikologi Pendidikan. Jakarta: Rineka Cipta.

Gunawan, Rudy. 2013. Pendidikan IPS. Bandung: CV.Alfabeta.

http//adintawindrapurnadari.blogspot.in/2013/05/v-behaviorurdefaultvmlo.html (diakses pada tanggal 24 Februari 2017 jam 21.00 wib).

Huda, Miftahul. 2013. Model-Model Pengajaran dan Pembelajaran. Yogyakarta: Pustaka Pelajar.

Idi, Abdullah. 2014. Pengembangan Kurikulum. Jakarta: PT Raja Grafindo Persada.

Khairani, Makmun. 2013. Psikologi Belajar. Yogyakarta: Aswaja Pressindo.

Kunandar. 2010. Langkah Mudah Penelitian Tindakan Kelas. Jakarta: PT Raja Grafindo Persada.

Kurniasih, Imas, dkk. 2015. Ragam Pembelajaran Model Pembelajaran. Yogyakarta: Kata Pena.

Mardianto. 2014. Psikologi Pendidikan. Medan: Perdana Publishing.

Mastur, dkk. 2007. Ilmu Pengetahuan Sosial untuk sekolah dasar. Semarang: Aneka Ilmu.

Muhibbin. 2011. Psikologi Belajar. Jakarta: Rajawali Pres.

Ngalim, dkk. 2011. Strategi dan Model Pembelajaran. Yogyakarta: Aswaja Presindo. 
Prastowo, Andi. 2013. Pengembangan Bahan Ajar Tematik. Yogyakarta: DIVA Press.

Sagala, Syaiful. 2005. Konsep dan Makna Belajar untuk membantu memecahkan problematika belajar dan mengajar. Bandung: Alfabeta.

Sapriya. 2009. Konsep dan Pembelajaran Pendidikan IPS. Bandung: Rosda Karya.

Suprijono, Agus. 2010. Cooperative Learning Teori dan Aplikasi PAIKEM. Yogyakarta: Pustaka Belajar.

Syah, Muhibbin. 2011. Psikologi Belajar. Jakarta: Rajawali Pres.

Trianti. 2012. Model Pembelajaran Terpadu konsep,strategi dan implementasinya dalam kurikulum tingkat satuan pendidikan. Jakarta: Bumi Aksara.

Umar, Bukhari. 2012. Hadis Tarbawi. Jakarta: Impi Bumi Aksara.

Usiono. 2015. Filsafat Pendidian Islam. Bandung: Cipta pustaka Media.

Zubaedi. 2011. Desain Pendidikan Karakter: Konsep dan Aplikasinya dalam Lembaga Pendidikan. Jakarta: Kencana. 
ISBN: 978-602-50622-0-9 